University of Nebraska - Lincoln

DigitalCommons@University of Nebraska - Lincoln

\title{
Adrenomedullin (AM) and adrenomedullin binding protein (AM- BP) in the bovine mammary gland and milk: Effects of stage of lactation and experimental intramammary $E$. coli infection
}

\author{
Ted H. Elsasser \\ USDA-ARS, elsasser@anri.barc.usda.gov \\ Anthony V. Capuco \\ USDA-ARS \\ Thomas J. Caperna \\ USDA-ARS \\ Alfredo Martínez \\ National Institutes of Health \\ Frank Cuttitta \\ National Institutes of Health \\ See next page for additional authors \\ Follow this and additional works at: https://digitalcommons.unl.edu/usdaarsfacpub \\ Part of the Agricultural Science Commons
}

\begin{abstract}
Elsasser, Ted H.; Capuco, Anthony V.; Caperna, Thomas J.; Martínez, Alfredo; Cuttitta, Frank; and Kahl, Stanislaw, "Adrenomedullin (AM) and adrenomedullin binding protein (AM-BP) in the bovine mammary gland and milk: Effects of stage of lactation and experimental intramammary E. coli infection" (2007). Publications from USDA-ARS / UNL Faculty. 685.

https://digitalcommons.unl.edu/usdaarsfacpub/685
\end{abstract}

This Article is brought to you for free and open access by the U.S. Department of Agriculture: Agricultural Research Service, Lincoln, Nebraska at DigitalCommons@University of Nebraska - Lincoln. It has been accepted for inclusion in Publications from USDA-ARS / UNL Faculty by an authorized administrator of DigitalCommons@University of Nebraska - Lincoln. 


\section{Authors}

Ted H. Elsasser, Anthony V. Capuco, Thomas J. Caperna, Alfredo Martínez, Frank Cuttitta, and Stanislaw Kahl 


\title{
Adrenomedullin (AM) and adrenomedullin binding protein (AM-BP) in the bovine mammary gland and milk: Effects of stage of lactation and experimental intramammary E. coli infection ${ }^{\text {负 }}$
}

\author{
Ted H. Elsasser ${ }^{\mathrm{a}, *}$, Anthony V. Capuco ${ }^{\mathrm{b}}$, Thomas J. Caperna ${ }^{\mathrm{a}}$, \\ Alfredo Martínez ${ }^{\mathrm{c}, 1}$, Frank Cuttitta ${ }^{\mathrm{c}}$, Stanislaw Kahl ${ }^{\mathrm{a}}$ \\ ${ }^{\text {a }}$ USDA-ARS, Growth Biology Laboratory, Beltsville, MD 20705, United States \\ b USDA-ARS, Bovine Functional Genomics Laboratory, Beltsville, MD, United States \\ ${ }^{\mathrm{c}}$ Departments of Cell and Cancer Biology, National Institutes of Health, \\ National Cancer Institute, Bethesda, MD 20892, United States
}

Received 21 December 2005; received in revised form 16 February 2006; accepted 17 February 2006

\begin{abstract}
Adrenomedullin (AM) has been characterized as an endogenous tissue survival factor and modulator of many inflammatory processes. Because of the increased susceptibility of the mammary gland to infection during the time surrounding parturition in the cow, we investigated how milk and tissue content of AM and its binding protein (AM-BP) might be affected by the stage of lactation and the udder health status. Milk and mammary biopsy samples were obtained from Holstein cows 21 days prior to and at various times after calving to represent the dry period and early and midstages of lactation. Additional cows received an intramammary challenge with Escherichia coli for immunohistochemical characterization of AM and AM-BP. Milk AM concentrations were relatively constant across the stages of lactation while AM-BP increased two-fold $(P<0.04)$ between early and

\footnotetext{
th This article is a U.S. Government work and, as such, is in the public domain in the U.S.A. Mention of a brand name or product does not constitute an endorsement of that product by the U.S. Government where other suitably related products are adequately functional in a similar application.

* Corresponding author at: USDA-ARS, Growth Biology Laboratory, B.A.R.C.-east, Beltsville, MD 20705, United Sates. Tel.: +1 301504 8281; fax: +1 3015048623.

E-mail address: elsasser@anri.barc.usda.gov (T.H. Elsasser).

${ }^{1}$ Present address: Department of Neuroanatomy and Cell Biology, Instituto Cajal (CSIC), Av. Dr. Arce 37, 28002 Madrid, Spain.
} 
mid-lactation. Milk AM $(P<0.04)$ and AM-BP $(P<0.03)$ increased as somatic cell counts $(\mathrm{SCCs})$ increased within a given stage of lactation. Tissue content of both (AM and AM-BP) were significantly affected by stage of lactation, lowest in the dry period and progressively increasing to peak at mid-lactation as well as increasing in association with higher levels of SCCs. Following E. coli challenge, AM increased in epithelial cells surrounding mammary alveoli presenting high levels of SCCs. The data suggest that AM and AM-BP are cooperatively regulated in the mammary gland during lactation; changes in localized tissue AM and AM-BP content reflect a dynamic regulation of these tissue factors in the bovine mammary gland consistent with their protective effects within inflamed tissue.

Published by Elsevier Inc.

Keywords: Adrenomedullin; Adrenomedullin binding protein; Mammary gland; Inflammation; Lactation

\section{Introduction}

Adrenomedullin (AM) is a 50-to-52 amino acid peptide, present in a myriad of tissues and is a member of the calcitonin gene-related (CGRP) family of bioactive peptides [1-3]. Following its discovery and characterization as a potent regulator of cardiovascular function [4,5], AM is now credited with a multiplicity of effects including autocrine growth regulation, angiogenesis and neoplasia, tissue differentiation and development, and regulation of metabolism [3]. More recently AM has been called a tissue survival factor [6] in that its upregulation during periods of proinflammatory stress has been linked to decreased apoptotic events [7], maintenance of tissue perfusion [8], localized antimicrobial peptide effects [9,10] and modulation of immune function [6,11]. Many actions of AM are tied to its interaction with the proinflammatory cytokine cascade including its regulation by endotoxin (LPS) and tumor necrosis factor- $\alpha$ (TNF- $\alpha,[12,13])$, as well as the generation of nitric oxide via several of the isoforms of nitric oxide synthase (NOS, [13-15]). We recently characterized a circulating protein that functions as a transport binding protein for AM (AM-BP, [16]). Further research into this binding protein revealed it to be a member of the complement cascade, namely, complement factor- $\mathrm{H}\left(\mathrm{C}-\mathrm{F}_{\mathrm{H}},[17]\right)$. The interaction of AM with AM-BP/C-F results in the modulation of the bioactivity of each component of the complex [17-19].

Cooperative work between our laboratories indicated that AM was present in several biofluids including human and bovine milk [20]. Because of its multiple effects on tissue function and survival as well as its properties as an antimicrobial peptide, we were interested to determine whether AM levels in bovine milk and mammary tissue might be associated with or reflective of the changes in udder health status and general mammary physiology that have been documented with regard to the impact of stage of lactation, especially around calving and presence of mammary infection [21-23]. Employing immunohistochemical image analysis techniques as well as RIA and Western blot approaches, we report here for the first time quantified localized changes in tissue AM and AM-BP in mammary tissue of cows, as well as changes in concentrations of AM and AM-BP in milk as a function of lactational status, milk somatic cell count, or presence of intramammary infection. 


\section{Materials and methods}

\subsection{Animals, milk samples and tissue specimen collection}

All cows used in this study were from the dairy herd of the Beltsville Agricultural Research Center. Cows were fed ad libitum, a herd diet (total mixed ration) that was formulated to meet National Research Council requirements for lactating cows. Water was available ad libitum by automated watering cups. Cows used for mammary biopsy were maintained in tie stalls for the duration of the experiment, while other cows were maintained in a free-stall environment. The Beltsville Agricultural Research Center's Animal Care and Use Committee approved the protocols, objectives and use of animals for this investigation.

To assess concentrations of AM in bovine milk during early and mid-lactation, milk samples were obtained from 26 lactating Holstein cows. Milk was collected at a single morning milking from 13 randomly selected cows during early lactation (12-62 days in milk), and 13 randomly selected cows during mid-lactation (124-198 days in milk). The milk samples were composited from the four quarters of each cow at the morning milking and aliquots prepared for determination of SCC, and analysis of AM and AM-BP. For determination of milk somatic cell count (SCC), milk samples were heated for 15 min at $60^{\circ} \mathrm{C}$ and maintained at $40^{\circ} \mathrm{C}$ until assayed on a Bentley Somacount 150 (Chaska, MN; [24]). Aliquots for AM and AM-BP analyses were kept on ice and processed within $2 \mathrm{~h}$, as described subsequently. Milk weights were recorded at the morning and evening milkings.

Expression of AM was studied in mammary tissue obtained during the nonlactating period (dry period) preceding successive lactations and during lactation. Five cows were dried-off 60 days before expected parturition and tissue obtained by mammary biopsy of the rear quarters 8 and 21 days after cessation of milking. Secretory tissue was obtained by biopsy from the right rear quarters prior to Escherichia coli injection as control samples and the challenged left rear quarters were biopsied $24 \mathrm{~h}$ after bacterial infusion. Biopsies ( $\sim 0.5-1 \mathrm{~g}$ tissue) were obtained from the upper half of the glands, using the biopsy method described by Farr et al. [25]. Mammary tissue was obtained from lactating cows associated with a previously reported experiment [26]. Tissues from lactating cows were collected at slaughter from four cows at days 14, 90 and 120 of lactation. Tissues were fixed in $10 \%$ neutral-buffered formalin at $4{ }^{\circ} \mathrm{C}$ overnight and processed for paraffin embedding and sectioning according to standard methods.

To evaluate the impact of coliform mastitis on expression of AM, tissues were obtained from three lactating Holstein cows during a previously reported experiment [27]. Briefly, at the beginning of the study all mammary quarters were healthy and noninfected. Prior to bacterial infusion, there was no difference in SCC between quarters used for control samples (right rear) and those used for postinfection analysis (left rear). E. coli challenge was performed immediately after a specified morning milking by gentle injection of a 2-ml volume containing 500 colony forming units of $E$. coli inoculum into the gland sinus of left front and left rear mammary quarters. The organism used was a serum-resistant E. coli, strain P-4, serotype O32:H37, which originally had been recovered from a cow with clinical mastitis and has been used in studies of E. coli mastitis. Secretory tissue was obtained by biopsy from the right rear quarters prior to $E$. coli injection as control samples and the challenged rear quarters were biopsied $24 \mathrm{~h}$ after bacterial injection from the upper half of 
the gland using the biopsy method described by Farr et al. [25]. For immunohistochemical analysis, biopsied tissues were placed in $10 \%$ neutral-buffered formalin and fixed at $4{ }^{\circ} \mathrm{C}$ overnight. Tissues were then processed for paraffin embedding and sectioning according to standard methods.

\subsection{Analytical techniques}

\subsubsection{Radioimmunoassay of milk adrenomedullin}

Milk concentrations of AM immunoreactivity were measured by a specific RIA as previously described and validated for plasma and milk $[13,20]$. Freshly obtained milk was maintained on ice and processed for AM extraction within $2 \mathrm{~h}$ of sampling. All procedures associated with AM were performed in polypropylene tubes. For extraction, $2.0 \mathrm{ml}$ milk was centrifuged for $10 \mathrm{~min}$ at $4{ }^{\circ} \mathrm{C}$ to separate milk fat, serum, and solids. Exactly $1.0 \mathrm{ml}$ of milk serum was drawn from under the fat and mixed with $1.0 \mathrm{ml}$ phosphate buffered saline ( $\mathrm{pH} 7.4$ ) containing $0.1 \%$ peptide matrix derived from the alkaline hydrolysis of casein (AHC) as described by Livesey and Donald [28] for the control of nonspecific adsorption of AM onto inert surfaces and other proteins and $0.1 \%$ Triton X-100. Extraction of AM was performed by reverse phase chromatography using C-18 SepPak ${ }^{\circledR}$ cartridges (Waters Corporation, Milford, MA) preconditioned with chloroform, methanol, $80 \%$ methanol/water, with a final prerinse with $1.8 \% \mathrm{NaCl}$. The $2.0 \mathrm{ml}$ milk/AHC mixture was allowed to permeate through the SepPak over $5 \mathrm{~min}$ and flushed with $3.0 \mathrm{ml}$ of $1.8 \% \mathrm{NaCl}$. AM was eluted from the column with $5.0 \mathrm{ml} 80 \%$ isopropanol in water. The resolved matrix was frozen in dry ice, and lyophilized to dryness overnight. For assay, the extraction residue was reconstituted in $400 \mu$ EDTA-PBS buffer containing $0.1 \%$ AHC and $0.05 \%$ Triton $\mathrm{X}-100$ and $20 \mathrm{mg} / \mathrm{l}$ phenol red. Samples displaying a yellow color after reconstitution were neutralized to approximately $\mathrm{pH} 7.5$ (pink color) using $<5 \mu \mathrm{l} 0.1 \mathrm{M} \mathrm{NaOH}$. The solution was transferred to $1.5 \mathrm{ml}$ conical microfuge tubes and centrifuged at $14,000 \mathrm{rpm}$ for $10 \mathrm{~min}$. One hundred microliters of each sample were assayed in triplicate in a total assay volume of $300 \mu \mathrm{l}\left(100 \mu \mathrm{l}\right.$ sample, $100 \mu \mathrm{l}{ }^{125}$ I-AM tracer, $100 \mu \mathrm{l}$ primary antibody). AM for standards (human AM 1-52), radiotracer $\left({ }^{125} \mathrm{I}-\mathrm{hAM}\right.$ ) as well as antibody (rabbit anti-human AM) were procured from Phoenix Pharmaceuticals, Inc. (Belmont, CA). All samples were analyzed in a single assay with a coefficient of variation between duplicates of $11.1 \%$, and a recovery of AM added to milk prior to extraction of $69 \%$ and a recovery of AM added to assay tubes of $97 \%$. Data are reported as assayed values corrected for average pre-extraction recovery.

\subsubsection{Western blot analysis of milk adrenomedullin binding protein}

Previous data derived from mass spectroscopy proteomic analysis of isolated and purified AM-BP has demonstrated that AM-BP and complement factor-H are one and the same [17], and that the initial localization and quantification of AM-BP by ${ }^{125}$ I-AM ligand blot [16] coincided with that derivable using Western blot analysis based on antibody against $\mathrm{C}-\mathrm{F}_{\mathrm{H}}$ [30]. Therefore, milk levels of AM-BP were measured by Western blot using rabbit anti-

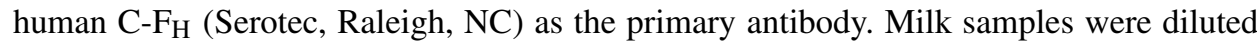
1:5 in pure water and centrifuged at $109,000 \times g$ for $20 \mathrm{~min}$ at $4{ }^{\circ} \mathrm{C}$, and further diluted at equal parts with Laemmli buffer (125 mM Tris-HCl, 10\% SDS, 10\% glycerol, pH 6.8, 
bromphenol blue tracking dye; final milk dilution, 1:10) containing 10\% $\beta$-mercaptoethanol. Samples were incubated in a boiling water bath for $5 \mathrm{~min}$ and cooled to room temperature. Proteins, electrophoretically separated through $8 \%$ acrylamide gels for $1.5 \mathrm{~h}$ at $110 \mathrm{~V}$, were transferred to polyvinylidene difluoride (PVDF, Immobilon- $\mathrm{P}^{\mathrm{TM}}$, Millipore Corp., Bedford, MA) membranes in a semi-dry electrotransfer apparatus (Bio-Rad, Hercules, CA). Membranes were incubated with primary antibody diluted 1:2000. Specific AM-BP bands were resolved using horseradish peroxidase-coupled secondary anti-rabbit antibodies and a fluorescent substrate (ECL-plus, GE Healthcare, Piscataway, NJ). Fluorescence intensity was measured using a Typhoon ${ }^{\circledR} 9400$ variable mode imager (GE Healthcare, Piscataway, $\mathrm{NJ}$ ) with band intensities determined and analyzed using ImageQuant ${ }^{\circledR}$ software.

\subsubsection{Quantitative immunohistochemistry for adrenomedullin and adrenomedullin binding protein}

Antibodies for AM and AM-BP immunohistochemistry were rabbit anti-AM (P-072,

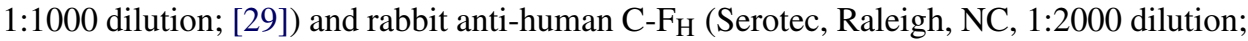
[30]). Mammary biopsy samples were embedded in paraffin, sectioned at $5 \mu \mathrm{m}$ and mounted on glass slides. Tissues were dewaxed in two successive $5 \mathrm{~min}$ xylene baths followed by one wash in absolute ethanol and a 30 min incubation in methanolic- $3 \%$ hydrogen peroxide to eliminate endogenous tissue peroxidase activity. Specimens were rehydrated through decreasing ethanol concentrations to water, transferred to Tris-buffered saline containing $0.05 \%$ Triton X-100 for $10 \mathrm{~min}$ followed by two $10 \mathrm{~min}$ baths in TRIS-saline. Nonspecific binding was blocked using 5\% normal goat serum in Tris-saline $(1 \mathrm{~h})$, followed by incubation overnight with the respective primary antibodies $\left(\sim 16 \mathrm{~h}, 4{ }^{\circ} \mathrm{C}\right)$. Antigens were visualized using the ABC method (Vectastain Elete ${ }^{\circledR}$ Rabbit Antibody Kit, Vector Laboratories, Burlingame, CA) with DAB as the substrate. Nuclei were counterstained for 2 min using Carazzi's hematoxylin. Slides were dehydrated through absolute ethanol, dipped in xylene and covered with glass cover slips. Quantitative image analysis for each antigen was performed as previously validated and published in our laboratory [31,32]. Three fields for each of 3 biopsy specimens per slide for each animal were captured using an Olympus BX40 microscope $(60 \times$ oil objective) fitted with an Olympus DP-70 digital camera. In order to ensure uniformity of the digital analysis of each slide, all images for a given antigen and for each animal were composed into a master image using Adobe Photoshop ${ }^{\circledR} \mathrm{CS}$ (Adobe Systems, Inc., San Jose, CA), and that master image subjected to the image analysis process. The individual frames of the composite image were then analyzed using the Image-Pro Plus Image Analysis Software (Version 4.5.1, MediaCybernetics Inc. Silver Spring, MD) through a standardized protocol. The composite images were equalized in terms of contrast, brightness, and gamma using the software-driven internal best-fit equalization algorithm. The intensity of DAB color-specific staining was obtained by defining through color-cubebased segmentation a spectrum-specific range of wavelengths, hues, and intensities that corresponded to those color attributes detectable by the same staining procedure applied to an internal control (pancreas) specimen known to contain positive immunostaining for AM and AM-BP. This spectral information was filed into a retrievable *.rge format that was subsequently used for analyzing all images. Specificity of staining was further refined in the software application cut-off criteria where object counts lower than a $3 \times 3$ pixel unit were eliminated. As defined in this manner, this analytical solution was found to be most 
commonly associated with false negative staining thus minimizing errors of false positive inclusion through this conservative rubric. Each estimate of tissue antigen staining intensity for an individual animal was obtained as the average of the summated pixels/field of the five images captured for each of two different tissue or biopsy specimens per slide. Because the mean number of cells per field may have differed as a function of mammary alveolar area (i.e., larger alveolar area in healthy mid-lactation glands may have resulted in a lower number of cells per field), additional image capture was obtained through the microscope as fitted with either the $60 \times$ and/or $100 \times$ objectives. In these instances, additional pixel counting was also performed on individual cells as marked using the free-form tool to outline cell membranes. Additional insight regarding populations of cells associated with defined mammary architecture and location (infiltrating somatic cells and alveolar epithelial cells) was obtained. Because many of the infiltrate cell types were immune cells with high intrinsic peroxidase activity, the completeness of peroxidase activity destruction by the methanolic peroxide incubation step was validated by not adding either primary antibody to a set of mammary tissue slides. Following the DAB reaction, the validation slides showed no color development substantiating the fact that color development in the SCC and alveolar infiltrating cells was specifically associated with an antigen-antibody reaction.

\subsubsection{Adrenomedullin in situ hybridization}

Assessment of tissue patterns of mRNA for AM was performed by in situ hybridization as described by Montuenga et al. [33]. We employed the full length AM cDNA ligated into the pCRII expression vector to generate the needed riboprobes. Generated plasmids were used as a template to assemble digoxigenin-labeled sense and antisense probes. The effects of infection on tissue patterns of AM mRNA were tested on mammary biopsy tissue obtained from the udder quarters of lactating Holstein cows challenged (infected) or not challenged with $E$. coli as described earlier in this manuscript. Following fixation, specimens were embedded in paraffin, sectioned $(5 \mu \mathrm{m})$ and mounted on slides using RNAase-protection protocols. Following xylene removal of paraffin, serial sections of tissue specimens were permeabilized with proteinase $\mathrm{K}(10 \mu \mathrm{g} / \mathrm{ml} ; 15 \mathrm{~min}$ with glycine quenching), acetylated with $0.25 \%$ acetic anhydride, washed and incubated in a humidified chamber $\left(18 \mathrm{~h} ; 46^{\circ} \mathrm{C}\right)$ with the sense and antisense probes, respectively. Following three rounds of stringency washes, mRNA was visualized using alkaline phosphatase-labeled anti-digoxigenin and BCIP-NBT as substrate.

\subsection{Statistical analysis of data}

Data were statistically analyzed using the general linear models procedure of the Statistical Analysis System (Proc GLM; [34]). For sections of the experiment dealing with the effects of lactation, the main effects tested were stage or day of lactation and SCC with stage-by-SCC tested for interaction. Animals were stratified and classed according to stage (early, $<60$ days after calving; mid-, $>60$ and $<200$ days after calving) or day (day 8, 21 of dry period, day 14, day 90, day 120 after calving) of lactation or SCC ranking (group1, SCC between 0 and 25,000; group 2 between 26,000 and 100,000; group 3>101,000 cells/ml milk). Justification for this stratification was largely empiric based on whether or not infiltrating mammary SCCs were not evident (group 1), rarely evident (group 2) or present in 
low numbers in several mammary alveoli evaluated in microscopic examination, though nonclinical in presentation (group 3). Animal within stage was used as the random error term.

\section{Results}

\subsection{Milk AM concentration and AM-BP content during lactation}

Concentrations of AM in milk did not differ between the early and mid-stages of lactation (Fig. 1). Concentrations of AM were relatively constant averaging approximately $250 \mathrm{pg} / \mathrm{ml}$. Concentrations of AM were, however, significantly affected by the prevailing somatic cell count within a given stage. Collectively, AM concentrations in milk increased with higher cell counts $(P<0.04)$. There was a significant stage-by-SCC interaction $(P<0.03)$.

Data generated by Western blot analysis of milk proteins to measure changes in the content of AM-BP are presented in Fig. 2. Milk AM-BP level was 2.2-fold higher $(P<0.04)$ in mid-lactation than that quantified for milk from cows in early lactation. Similar to the changes in AM that were associated with somatic cell count, milk AM-BP level was also affected by somatic cell count $(P<0.03)$. Milk AM-BP was not statistically different between groups 1 and 2; mean milk AM-BP was two-fold higher in milk from cows presenting somatic cell counts greater than 100,000 cells/ml (group 3) than that associated with milk from groups 1 and 2 . As with milk AM concentrations, there was a significant stage-by-SCC interaction for milk levels of AM-BP.

\subsection{Immunohistochemical localization of $A M$ and $A M-B P$ in the mammary gland}

The cellular presentation of AM in mammary tissue at the indicated stages or days of lactation as well as the summarized statistical quantification of antigen-specific colored pixels

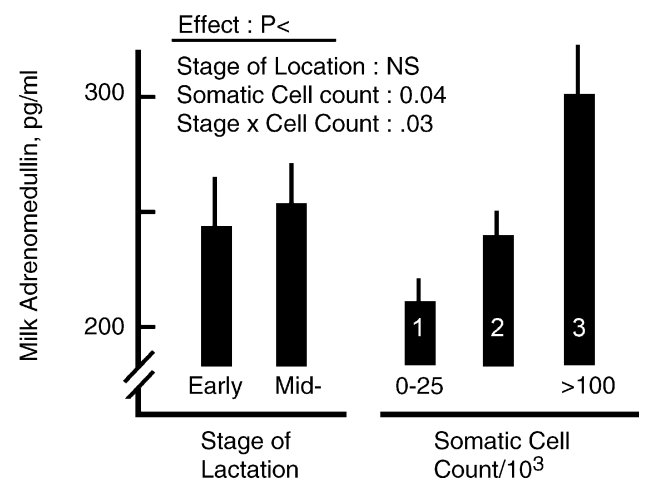

Fig. 1. Concentrations of adrenomedullin in milk in early and mid-lactation and as affected by grouping by somatic cell counts. Bars represent least squares mean values ( \pm pooled S.E.) of 12 cows at early and 14 cows at midlactation; numbers within the bars associated with the graphic section from somatic cell count effects represent the group identities as segregated by the cell count ranges shown (group 1, $n=11$; group 2, $n=7$; group 3, $n=8$ ). 

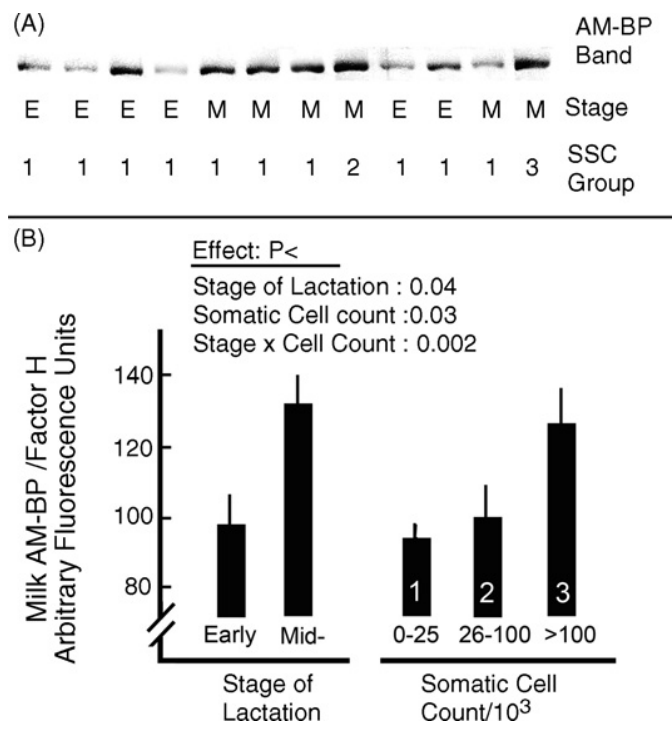

Fig. 2. Concentrations of adrenomedullin binding protein (AB-BP) in milk in early and mid-lactation and as affected by grouping by somatic cell counts. Panel (A) Representatative Western blot of AM-BP/complement factor-H in milk from 12 animals at different stages of lactation and somatic cell count values. Panel (B) Bars represent least squares mean values ( \pm pooled S.E.) of 12 cows at early and 12 cows at mid-lactation; numbers within the bars associated with the graphic section from somatic cell count effects represent the group identities as segregated by the cell count ranges shown (group 1, $n=11$; group 2, $n=7$; group 3, $n=8$ ).

are presented in Fig. 3. Whereas the upper panel of the microphotographs clearly depicts true antigen immunostaining (DAB, brownish-red color) contrasting with the Carrazzi's hematoxylin-stained nuclei, the lower panel depicts in red the pixels that the image analysis algorithm has identified as counted in association with the antigen. The image shows that

\section{Days into Lactation}

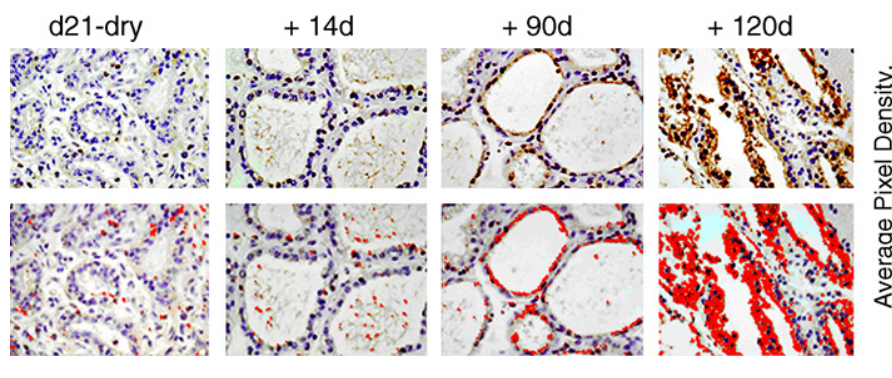

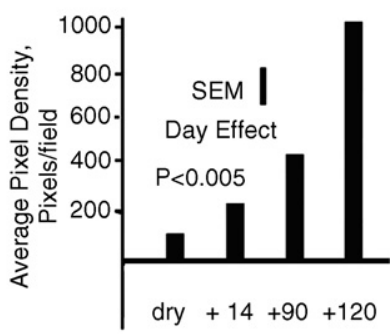

Fig. 3. Tissue AM antigen presentation as quantified by digital image analysis in mammary biopsy tissue from Holstein cows at different physiological stages and days into lactation. (Top panel) Direct immunohistochemical (IHC) microphotographs obtained using rabbit anti-AM primary antibody with avidin-biotin enhanced visualization accomplished with a horseradish peroxidase-DAB (reddish-brown color) reaction. (Bottom panel) Representative output (red pixels) from the image analysis algorithm used to quantify specific DAB immunostaining. (Right panel) Statistical representation of collated IHC image analysis data. $N=3-4$ cows per group; 3-4 biopsy samples per cow. 


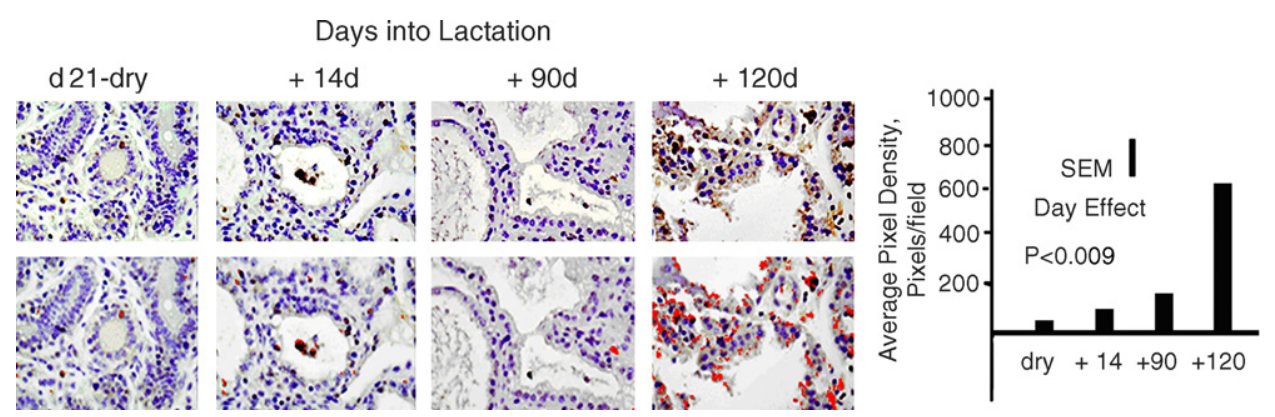

Fig. 4. Tissue AM-BP antigen presentation as quantified by digital image analysis in mammary biopsy tissue from Holstein cows at different physiological stages and days into lactation. (Top panel) Direct immunohistochemical (IHC) microphotographs obtained using rabbit anti-complement factor-H/AM-BP primary antibody with avidin-biotin enhanced visualization accomplished with a horseradish peroxidase-DAB (reddish-brown color) reaction. (Bottom panel) Representative output (red pixels) from the image analysis algorithm used to quantify specific DAB immunostaining. (Right panel) Statistical representation of collated IHC image analysis data. $N=3-4$ cows per group; $3-4$ biopsy samples per cow.

AM is mainly associated with the epithelial cells lining the lumen of the mammary secretory alveoli, as well as some individual somatic cells identified as infiltrating neutrophils (based upon morphological criteria) within the alveolar lumen. Furthermore, the intensity of staining (i.e., antigen presence) is lowest in tissue from animals in the dry period and almost doubled in intensity (pixel density) from day 14 of lactation through day 120 (bar graph segment of Fig. 3).

The accompanying AM transport protein AM-BP was localized in a cellular pattern similar to that observed for AM (Fig. 4). Though lower in intensity than the corresponding AM immunostaining, the consistent significant pattern for AM-BP indicated almost no presence in tissues of animals in the dry period, again, with antigen localization increasing with days into lactation to a maximum at mid-lactation. Analysis of data by a separation on means indicated no difference in AM-BP levels between the dry period and day 14 of lactation; however, levels significantly higher than these were evident at days 90 and 120 into lactation with a further significant increase developing between days 90 and 120 . The increase at measured peak was approximately seven-fold higher than that quantified for samples from cows in the dry period or day $14(P<0.006)$.

\subsection{AM and AM-BP responses to E. coli challenge in the mammary gland}

Image analysis of photomicrographs of responses in AM and AM-BP within the mammary gland to experimental infection with E. coli indicated that AM increased in conjunction with a decrease in AM-BP (Fig. 5). Consistent with the previously observed increase in tissue AM with increased SCC in otherwise healthy animals, the challenge with E. coli prompted an increase in tissue AM from two sources: somatic cells infiltrating the gland and a relative increase in epithelial presence marked by less diffuse punctuate and more tightly condensed granules of a larger area (volume). Statistical analysis of the image analysis quantification data indicated that the AM response to E. coli challenge constituted a three-fold increase in 


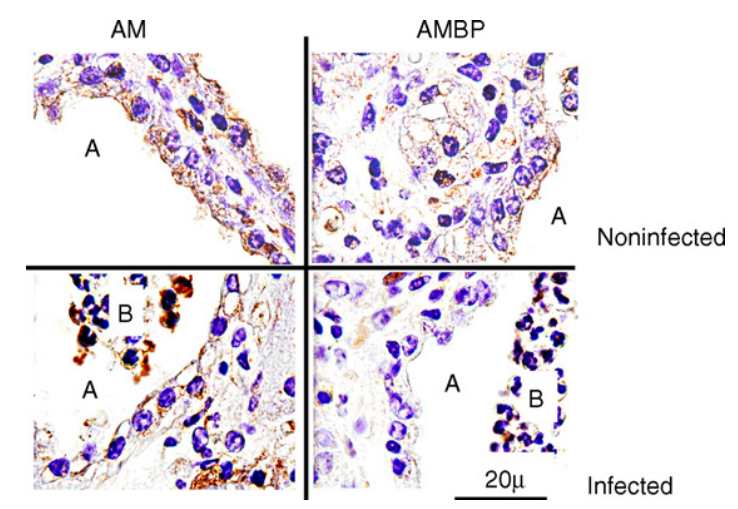

Fig. 5. Adrenomedullin and AM-BP response in mammary tissue biopsy samples typical of those mammary quarters that served as normal and infected with E. coli. The areas designated as "A" indicate luminal areas of the glandular structure; areas denoted by "B" indicate the presence of infiltrating SCCs.

AM in the mammary epithelial cells, not counting the larger increase in AM in the infiltrating SCC. In contrast, antigen levels of AM-BP decreased by $70 \%(P<0.02)$ in mammary epithelial luminal cells; Where detectable in individual SCC, the AM-BP antigen density levels measured where detectable in individual SCC (using a free-form outlining tool in the Image-Pro analytical software) were approximately twice the density of epithelial cells expressing AM-BP. Interestingly, the response in the SCC was an all-or-nothing response where cells either had high levels of antigen or none at all.

Corroboration on the effect of the coliform-associated inflammatory response on AM within the challenged mammary quarters was made by assessing the regulatory status of the infection on AM mRNA expression via in situ hybridization. As presented in Fig. 6, when the antisense probe was hybridized to mammary AM mRNA, microscopic examination of the tissue sections showed that the pattern of AM expression basically mirrored that of the peptide antigen staining (Fig. 5) observed with immunohistochemistry in normal and infected tissue. However, in association with experimental infection with E. coli, AM mRNA product staining was increased not only in the clustered infiltrating SCCs and the lumen

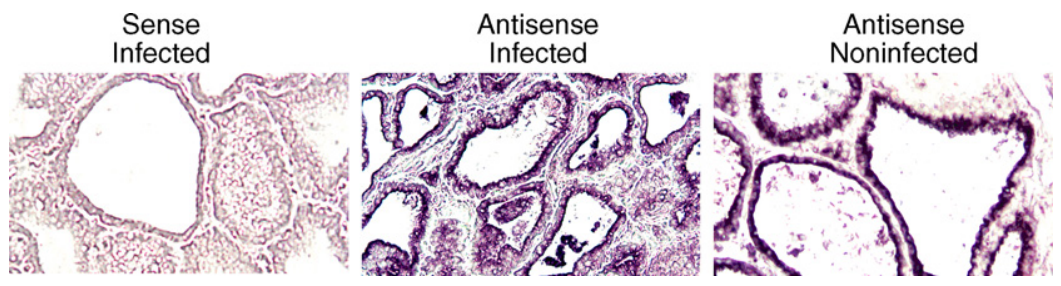

Fig. 6. Adrenomedullin mRNA expression patterns visualized by in situ hybridization in mammary biopsy samples collected from lactating cows $(n=3)$ each with one quarter challenged with saline and another quarter challenged with E. coli. Specific dark gray-to-black staining was generated by the alkaline phosphatase-associated reporter coupled to anti-digoxigenin where the digoxygenin-coupled riboprobe hybridized to the endogenous AM mRNA (middle and right panels). The digoxygenin-labeled sense probe (left panel) failed to generate significant signal and was used to correct for nominal background in the image analysis process. 
boarder epithelial cells, but also in stromal cells within the tissue matrix and in association with several of the blood vessels present in the various sections.

\section{Discussion}

As relates to the periparturient cow and its varying levels of immunocompetence, we asked whether tissue-specific changes in AM and its binding protein AM-BP are localized to the mammary gland or associated with differences in milk content at a given stage of lactation. Using in situ hybridization and sensitive quantitative immunohistochemical techniques for tissue analysis as well as Western blot and radioimmunoassay for AM-BP and AM in milk, respectively, we discovered that there was a significant change in the content of AM and AM-BP, in mammary alveolar cells, there was little change in milk concentrations of AM, but significant change in milk AM-BP as a function of lactation stage. Perhaps the greatest factor affecting milk concentrations of AM and AM-BP was the presence of infiltrating neutrophils (somatic cells) suggesting some level, albeit low, of invasion by a foreign body (bacteria or otherwise). In general, a higher level of SCC was associated with a higher level of AM and AM-BP. The data in this report that address the relationship between SCC and adrenomedullin are for milk collected from cows in the herd irrespective of bacteriological status. Milk was normal in appearance, without flakes or clots. Evaluation of AM over a range of SCC was done without regard to bacteriological status of the quarters. Visual examination of the hematoxylin/eosin-stained histological sections suggest that the vast majority of SCC were neutrophils, i.e. their size, intracellular morphology and polymorphic nuclei were consistent with a predominance of neutrophillic infiltration. Comparing tissues obtained from cows in different stages of lactation, we observed that the lowest level of expressed AM in the mammary gland occurred in tissue sections obtained from cows during the dry period and shortly after calving. Similarly, introduction of a pathogen $(E$. coli) to the mammary gland resulted in increased transcript levels for AM and accompanying increases in tissue associated AM antigen. Interestingly, infiltrating cells presented the highest AM antigen density in the infected alveoli with the second highest level of expression present on luminal surface of epithelial cells lining the mammary alveoli on the luminal surface. The determination of success in eliminating inherent SCC-associated peroxidase activity provided further validation of the greater intensity of antigen presence in these cells. The present data confirms and extends our previous data [20] on relative AM content in milk with the tissue data on AM and AM-BP. Furthermore, the milk AM data presented here support the previous observation that milk AM concentrations were relatively stable across days of lactation. With regard to E. coli infection of the mammary gland, a prominent feature of the staining pattern was the tight association of antigen (granules) with the luminal surface of the epithelial cells suggesting secretion of AM or externalization of AM to the outside surface where the peptide would be more directly exposed to the pathogen, possibly leading to protection of affected alveolar epithelial cells. The report by Welsh et al. [35] supports this concept wherein they described the presence of AM in the apical protrusions of human breast epithelium, being secreted to the lumen by an apocrine mechanism.

The time around calving is recognized as a period of increased disease incidence in cows $[22,23,36-38]$. Periparturient susceptibility to disease is attributed to residual degrees 
of compromised immune functions that persist as a carryover from hormone and cytokine interactions that were needed to maintain pregnancy (i.e., pregnancy-related immunosuppression to prevent embryonic allograph rejection by maternal tissues, [38,39]), but are in fact in the process of being downregulated as fetal maturation signals prompt the initiation of separation of the calf from the mother at parturition [40]. Present day management strategies of cows during this transition period call for health maintenance through antibiotic regimens as well as nutritional strategies to lessen the impact of metabolic syndromes that can potentiate additional sensitivity to infection by opportunistic bacteria, especially with regard to intramammary infection [41]. Our laboratory has been interested in how novel aspects of innate or naturally present defense mechanisms might be better exploited in cows to improve the chances for more rapid and beneficial outcome from exposures to pathogens in this critical period. Our experience has suggested that endogenous multifunctional peptides, when upregulated during periods of stress, bridge and coordinate effects on metabolism and immune function, and yet having novel antimicrobial activity, serve as important biomarkers that can be utilized for selecting breeding animals with desirable production and health traits $[6,38]$.

Adrenomedullin is now recognized as a key peptide in many tissues in many species that serves as a coordinating tissue survival factor in many species during decompensating stress $[6,7,42]$. Examples of activity include its capacity to ameliorate regional ischemic events and blood shunting during sepsis by maintaining local tissue oxygen perfusion and blood flow [43], reducing tissue necrosis and apoptosis through AM/AM-BP complex-augmented production of anti-apoptotic BCL-2 cascade factors and concomitantly decreased pro-apoptotic Bax gene expression [44], effects on pancreatic hormone secretion and localized tissue metabolic responses to pancreatic hormones [13,29,30], interactions with the LPS-TNF$\alpha$-nitric oxide cascade $[12,13,38]$, and its effects to neutralize growth and pathogenic activities of both Gram-negative and Gram-positive [8-10] bacteria.

Collectively, the present data indicate that tissue and milk levels of AM and AM-BP change throughout the lactation cycle especially as affected by underlying conditions that promote the migration of infiltrating somatic cells into the mammary alveoli. The generalized upregulation (i.e., increased tissue antigen presence) of AM and AM-BP in association with increased somatic cell count suggests that in cases of very low level foreign body challenge (inert particulate, pathogen or otherwise) there exists a tight coordination between these factors that may play a role in the acute and chronic maintenance of udder health. When the inflammatory state develops, as experimentally induced here by the infusion of E. coli, there appears to develop a functional disconnect between AM and AM-BP, such that direct effects of AM on host immune processes are increased not only though increased AM production, but in addition through a decreased association of AM with its binding protein. This is consistent with previous observations clearly showing that many physiological actions of AM are prevented from occurring when AM is bound to its binding protein, as is the ability of AM-BP, complement factor- $\mathrm{H}$, to modulate aspects of the complement cascade $[17,18]$. A key example of this was demonstrated when exogenous AM-BP was added to AM causing a significant portion of the antibacterial effect of AM to be lost. Conversely, if tissue levels of endogenous AM-BP are decreased and AM peptide increased in mammary tissue and infiltrating cells during coliform mastitis, then it stands to reason that the potential for beneficial effects of AM-driven antimicrobial control 
of mastitis are increased, likely complementing other innate countermeasures that may be similarly affected. In line with this direct effect on bacteria $[9,10]$, the upregulation of AM is consistent with other homeostatic actions of AM, some in part mediated by the action of AM to increase local production of nitric oxide. They include increased mammary blood flow facilitating delivery of neutrophils, complement factors and chemotactic factors to the gland stabilization and attenuation of bacterial toxin-related apoptosis, counter-regulation of adverse proinflammatory cytokine release, and facilitated augmentation of growth factor production including IGF-1 [38,43,45-48]. Exactly how AM affects the biological activity of AM-BP towards processing of complement $\mathrm{C} 3$ and the progression through the complement cascade towards complement $\mathrm{C} 5$-mediated chemotactic attraction of monocytes, granulocytes and neutrophils [49] to sites of mammary infection remains unknown.

With regard to the immunolocalization of AM in mammary cells and structures, a prominent feature of the staining pattern was the tight association of antigen (granules) with the luminal surface of the epithelial cells. This would be consistent with a process involving secretion of AM or externalization of AM to the outside surface where the peptide would be more directly exposed to the pathogen in a mechanism protective to the affected mammary gland cells. We consider the antimicrobial actions of AM significant with regard to the potential for the mammary gland to help itself in times of incurred pathogen challenge through the local production of an endogenous peptide such as AM. Allaker et al. [50] investigated the mechanism by which AM exerts many of its antimicrobial properties. In essence, AM generates pore formation and cell wall disruption in E. coli. Processing of AM may be an important determinant of AM antimicrobial activity in that differences in minimal inhibitory concentrations (MIC) were associated with different molecular forms of the native 52 amino acid. In particular, the fragments of AM with greatest antimicrobial activity were $\mathrm{AM}_{13-52}$ and $\mathrm{AM}_{16-52}$, the carboxy terminal region having more activity than amino-terminal areas. Suggested in this research was the idea that post-secretory processing generates a myriad of AM subsets with a range of targets. This multiform approach to antimicrobial activity may reduce the likelihood of the development of resistance. Furthermore, this processing to fragments of AM underscores the relevance of the total AM-like immunoreactivity concentrations reported here for milk in contrast to the lower levels of AM in milk reported by Ohta et al. [51] using an immunoradiometric assay that presumably quantified presumable only one form of AM. However, the higher levels of AM reported for milk in the present study may reflect a fundamental species difference in expression, secretion and processing.

Depending on the biological effect observed, the interaction of AM with AM-BP can facilitate or retard the action of each component in the complex. For example, a reciprocal interaction is imparted on biological properties of AM when it is bound to the complement factor-H binding protein. AM antimicrobial peptide activity against $E$. coli is significantly reduced when AM is linked to its binding protein. Pio et al. [17] demonstrated that the minimal inhibitory concentration of AM effective against $E$. coli shifted from 10 to more than $35 \mu \mathrm{g} / \mathrm{ml}$ when AM was complexed with AM-BP. Interestingly, the activity of AM$\mathrm{BP}$ as complement factor-H (responsible cofactor for the factor I-dependant cleaving of complement $\mathrm{C} 3 \mathrm{~B}$ ) is increased when $\mathrm{AM}$ is bound [17] suggesting that aspects of the innate complement cascade within the mammary gland [49] are also modulated by AM. Furthermore, increased beneficial clinical outcome (decreased morbidity and mortality) 
recently has been attributed to the use of an AM/AM-BP complex as an intervention strategy to limit the complicating effects of sepsis and hypovolumic shock on progression into multiple organ failure [19,42-44].

The importance of these observations relate to the inherent capacity for the mammary gland to mount defenses against invading pathogens that could trigger clinical mastitis. This defense may include the local production of inflammatory cytokines [52], generation of superoxide anion via mammary xanthine oxidase [53] and nitric oxide [47,54,55]. First, the tissue content of AM as an antimicrobial peptide capacity of AM is lowest at the time when it is most needed. This is also the case for lactoferrin and other endogenous peptides in milk [38] that, as a collective milieu, form one of the basic compartmentalized local mediators of mammary tissue health, not unlike that present in epidermal skin, the respiratory tract, and even the GI tract [9]. In this regard, we can also envision a potential compromise of the nitric oxide and superoxide anion defense mechanisms since these are also lowest at this time period, though presently this area of mammary biology in the bovine is poorly studied. In addition, the tightly coordinated regulation of AM and nitric oxide make a strong case for blood flow in the mammary gland is regulated by the local production of these vascular mediators [47]. The data presented here extend our knowledge of AM in cattle and serve as a launch point for further investigation regarding the merit of using AM and AM-BP as biomarkers for mammary health and their utility for selecting animals with an improved capacity to resist mastitis through endogenous mechanism.

\section{Acknowledgement}

A.M. is supported by a grant from the Spanish Ministry of Science and Education, BFU2004-02838.

\section{References}

[1] López J, Martínez A. Cell and molecular biology of the multifunctional peptide, adrenomedullin. Int Rev Cytol 2002;221:1-92.

[2] Muff R, Born W, Fischer JA. Calcitonin, calcitonin gene-related peptide, adrenomedullin and amylin: homologous peptides, separate receptors and overlapping biological actions. Eur J Endocrinol 1995;133(1): 17-20.

[3] Cuttitta F, Miller MJ, Montuenga LM, Garayoa M, Elsasser TH, Walsh T, et al. Adrenomedull: terra ingognita. In: Martínez A, Cuttitta F, editors. Adrenomedullin. Washington, DC: IOS Press/Oshima; 1998. p. 1-26 [Review].

[4] Kitamura K, Kangawa K, Kawamoto M, Ichiki Y, Nakamura S, Matsuo H, et al. Adrenomedull: a novel hypotensive peptide isolated from human pheochromocytoma. Biochem Biophys Res Commun 1993;192(2):553-60.

[5] Ishiyama Y, Kitamura K, Ichiki Y, Nakamura S, Kida O, Kangawa K, et al. Hemodynamic effects of a novel hypotensive peptide, human adrenomedullin, in rats. Eur J Pharmacol 1993;241(2-3):271-3.

[6] Elsasser TH, Kahl S. Adrenomedullin has multiple roles in disease stress: development and remission of the inflammatory response. Microsc Res Tech 2002;57(2):120-9.

[7] Kato H, Shichiri M, Marumo F, Hirata Y. Adrenomedullin as an autocrine/paracrine apoptosis survival factor for rat endothelial cells. Endocrinology 1997;138(6):2615-20. 
[8] Brell B, Temmesfeld-Wollbruck B, Altzschner I, Frisch E, Schmeck B, Hocke AC, et al. Adrenomedullin reduces Staphylococcus aureus $\alpha$-toxin-induced rat ileum microcirculatory damage. Crit Care Med 2005;33(4):819-26.

[9] Allaker RP, Zihni C, Kapas S. An investigation into the antimicrobial effects of adrenomedullin on members of the skin, oral, respiratory tract and gut microflora. FEMS Immunol Med Microbiol 1999;23(4): 289-93.

[10] Allaker RP, Kapas S. Adrenomedullin expression by gastric epithelial cells in response to infection. Clin Diag Lab Immunol 2003;10(4):546-51.

[11] Brogden KA, Guthmiller JM, Salzet M, Zasloff M. The nervous system and innate immunity: the neuropeptide connection. Nat Immunol 2005;6(6):558-64.

[12] Minamino N, Isumi Y, Kangawa K, Kitamura K, Matsuo H. Adrenomedullin production in vascular cells and its function in the vascular wall. In: Martínez A, Cuttitta F, editors. Adrenomedulin. Washington, DC: IOS Press/Oshima; 1998. p. 79-102.

[13] Elsasser TH, Sartin JL, Martínez A, Kahl S, Montuenga L, Pio R, et al. Underlying disease stress augments plasma and tissue adrenomedullin (AM) responses to endotoxin: colocalized increases in A.M. inducible nitric oxide synthase within pancreatic islets. Endocrinology 1999;140:5402-11.

[14] Jougasaki M, Burnett JC. Adrenomedullin: potential in physiology and pathophysiology. Life Sci 2000;66:855-72.

[15] Minamino N, Kangawa K, Matsuo H. Adrenomedullin: a new peptidergic regulator of the vascular function. Clin Hemorheol Microcircul 2000;23(2-4):95-102.

[16] Elsasser TH, Kahl S, Martínez A, Montuenga LM, Pio R, Cuttitta F. Adrenomedullin binding protein in the plasma of multiple species: characterization by radioligand blotting. Endocrinology 1999;140: 4908-11.

[17] Pio R, Martínez A, Unsworth EJ, Kowalak JA, Bengoechea JA, Zipfel PF, et al. Complement factor H is a serum-binding protein for adrenomedullin, and the resulting complex modulates the bioactivities of both partners. J Biol Chem 2001;276:12292-300.

[18] Pio R, Elsasser TH, Martinez A, Cuttitta F. Identification, characterization, and physiological actions of factor $\mathrm{H}$ as an adrenomedullin binding protein present in human plasma. Microsc Res Tech 2002;57(1):23-7.

[19] Cui X, Wu R, Zhou M, Dong W, Ulloa L, Yang H, et al. Adrenomedullin and its binding protein attenuate the proinflammatory response after hemorrhage. Crit Care Med 2005;33(2):391-8.

[20] Pio R, Martinez A, Elsasser TH, Cuttitta F. Presence of immunoreactive adrenomedullin in human and bovine milk. Peptides 2000;21(12):1859-63.

[21] Ingvartsen KL, Dewhurst RJ, Friggens NC. On the relationship between lactational performance and health: is it yield or metabolic imbalance that cause production disease in cattle? A position paper. Livestock Prod Sci 2003;83:277-308.

[22] Goff JP, Horst RL. Physiological changes at parturition and their relationship to metabolic disorders. J Dairy Sci 1997;80:1260-8.

[23] Burton JL, Madsen SA, Yao J, Sipkovsky SS, Coussens PM. An immunogenomics approach to understanding periparturient immunosuppression and mastitis susceptibility in cows. Acta Vet Scand 2001;42:407-24.

[24] Capuco AV, Rice CP, Baldwin 6th RL, Bannerman DD, Paape MJ, Hare WR, et al. Fate of dietary perchlorate in lactating dairy cows: Relevance to animal health and levels in the milk supply. Proc Natl Acad Sci USA 2005;102:16152-7.

[25] Farr VC, Stelwagen K, Cate LR, Molenaar AJ, McFadden TB, Davis SR. An improved method for the routine biopsy of bovine mammary tissue. J Dairy Sci 1996;79:543-9.

[26] Capuco AV, Wood DL, Baldwin R, McLeod K, Paape MJ. Mammary cell number, proliferation, and apoptosis during a bovine lactation: relation to milk production and effect of bST. J Dairy Sci 2001;84:2177-87.

[27] Long E, Capuco AV, Wood DL, Sonstegard T, Tomita G, Paape MJ, et al. Escherichia coli induces apoptosis and proliferation of mammary cells. Cell Death Diff 2001;8:808-16.

[28] Livesey JH, Donald RA. Prevention of adsorption losses of polypeptide hormones: effectiveness of albumins, gelatin, caseins, Tween-20 and plasma. Clin Chem Acta 1982;123:193-8.

[29] Martínez A, Weaver C, Lopez J, Bhathena SJ, Elsasser TH, Miller MJ, et al. Regulation of insulin secretion and blood glucose metabolism by adrenomedullin. Endocrinology 1996;137(6):2626-32.

[30] Martínez A, Pio R, Lopez J, Cuttitta F. Expression of the adrenomedullin binding protein, complement factor $\mathrm{H}$, in the pancreas and its physiological impact on insulin secretion. J Endocrinol 2001;170(3):503-11. 
[31] Elsasser TH, Kahl S, MacLeod C, Nicholson B, Sartin JL, Li C. Mechanisms underlying growth hormone effects in augmenting nitric oxide production and protein tyrosine nitration during endotoxin challenge. Endocrinology 2004;145(7):3413-23.

[32] Daniel JA, Elsasser TH, Martinez A, Steele B, Whitlock BK, Sartin JL. Interleukin-1 $\beta$ and tumor necrosis factor- $\alpha$ mediation of endotoxin action on growth hormone. Am $\mathrm{J}$ Physiol Endocrinol Metab 2005;289(4):E650-7.

[33] Montuenga LM, Martínez A, Miller MJ, Unsworth EJ, Cuttitta F. Expression of adrenomedullin and its receptor during embryogenesis suggests autocrine or paracrine modes of action. Endocrinology 1997;138: 440-51.

[34] SAS Users Guide. Cary, NC: SAS Institute; 1995.

[35] Welsch U, Unterberger P, Höfter E, Cuttitta F, Martínez A. Adrenomedullin in various mammalian and human skin glands including the mammary gland. Acta Histochem 2002;104:65-72.

[36] Dingwell RT, Kelton DF, Leslie KE. Management of the dry cow in control of peripartum disease and mastitis. Vet Clin N Am Food Anim Practice 2003;19:235-65.

[37] Ingvartsen KL, Andersen JB. Integration of metabolism and intake regulation: a review focusing on periparturient animals. J Dairy Sci 2000;83:1573-97.

[38] Elsasser TH, Ingvartsen KL, Kahl S, Capuco AV. Endocrine effects on immune function: defining opportunities based on knowledge from growing calf and periparturient animal models. In: Sejrsen K, Hvelplund T, Nielsen MO, editors. Ruminant physiology. Wageningen, The Netherlands: Wageningen Academic Publishers; 2005. p. 415-47.

[39] Rogers AM, Boime I, Connolly J, Cook JR, Russel JH. Maternal-fetal tolerance is maintained despite transgene-driven trophoblast expression of MHC class I, and defects in FAS and its ligand. Eur J Physiol 1998;28:3479-87.

[40] Schwartz J, McMillen IC. Fetal-hypothalamic-pituitary-adrenal axis on the road to parturition. Clin Exp Pharmacol Physiol 2001;28:108-12.

[41] Ingvartsen KL, Dewhurst RJ, Friggens NC. On the relationship between lactational performance and health: is it yield or metabolic imbalance that cause production disease in cattle? A position paper. Livestock Prod Sci 2003;83:277-308.

[42] Nishikimi T, Yoshihara F, Mori Y, Kangawa K, Matsuoka H. Cardioprotective effect of adrenomedullin in heart failure. Hypertens Res 2003;26(Suppl):S121-7.

[43] Yang S, Zhou M, Chaudry IH, Wang P. Novel approach to prevent the transition from the hyperdynamic phase to the hypodynamic phase of sepsis: role of adrenomedullin and adrenomedullin binding protein-1. Ann Surg 2002;236:625-33.

[44] Zhou M, Simms HH, Wang P. Adrenomedullin and adrenomedullin binding protein-1 attenuate vascular endothelial cell apoptosis in sepsis. Ann Surg 2004;240:321-30.

[45] Craven N. Chemotactic factors for bovine neutrophils in relation to mastitis. Comp Immunol Microbiol Infect Diseases 1986;9(1):29-36.

[46] Barrio MB, Rainard P, Poutrel B. Milk complement and the opsonophagocytosis and killing of Staphylococcus aureus mastitis isolates by bovine neutrophils. Microb Pathogesis 2003;34(1):1-9.

[47] Lacasse P, Far VC, Davis SR, Prosser CG. Local secretion of nitric oxide and the control of mammary blood flow. J Dairy Sci 1996;79:1369-74.

[48] Bruckmaier RJ, Schillibaum M, Blum JW. Escherichia coli endotoxin-induced mastitis in dairy cows: changes and importance of insulin-like growth factor-1 and oxytocin. Milk Sci Int 1993;48:374-8.

[49] Rainard P. Bovine milk fat globules do not inhibit C5a chemotactic activity. Vet Res 2002;33: 413-9.

[50] Allaker RP, Grosvenor PW, McAnerney DC, Sheehan BE, Srikanta BH, Pell K, et al. Mechanisms of adrenomedullin antimicrobial action. Peptides 2005 [Epub ahead of print].

[51] Ohta N, Tsukahara H, Ohshima Y, Nishii M, Ogawa Y, Sekine K, et al. Nitric oxide metabolites and adrenomedullin in human breast milk. Early Hum Develop 2004;78(1):61-5.

[52] Schmitz S, Phaffl MW, Meyer HHD, Bruckmaier RM. Short-term changes of mRNA expressions of various inflammatory factors and milk proteins in mammary tissue during LPS-induced mastitis. Domest Anim Endocrinol 2004;26:111-26.

[53] Collins RA, Paarsons KR, Field TR, Bramley AJ. Histochemical localization of xanthine oxidase in the bovine mammary gland. J Dairy Res 1988;55:25-32. 
[54] Komine K, Kuroishi T, Komine Y, Watanabe K, Kobayashi J, Yamaguchi T, et al. Induction of nitric oxide production mediated by tumor necrosis factor- $\alpha$ on Staphylococcal enterotoxin C-stimulated bovine mammary gland cells. Clin Diag Lab Immunol 2004;11:203-10.

[55] Blum JW, Dosogne H, Hoeben D, Vangroenweghe F, Hammon HM, Bruckmaier RM, et al. Tumor necrosis factor- $\alpha$ and nitrate/nitrite responses during acute mastitis induced by Escherichia coli infection and endotoxin in dairy cows. Domest Anim Endocrinol 2000;19:223-35. 